\title{
TREATMENT OF INFLAMMATORY BOWEL DISEASE AND PREGNANCY: a review of the literature
}

\author{
Lucianna Motta CORREIA, Danielle Queiroz BONILHA, Juliana Dantas RAMOS, \\ Orlando AMBROGINI and Sender Jankiel MISZPUTEN
}

\begin{abstract}
Context - The inflammatory bowel disease is diagnosed frequently among woman of childbearing capacity. The management must be carefully because there are potential risks for the mother and fetus. Results and conclusions - We review literature about the management of inflammatory bowel disease in pregnancy. Some studies are needed to ensure the best approach to inflammatory bowel disease in pregnant women.
\end{abstract}

HEADINGS - Inflammatory bowel disease. Pregnancy complications, infectious. Infliximab.

\section{INTRODUCTION}

Inflammatory bowel disease (IBD) frequently affects women in childbearing age. During pregnancy, clinical exacerbations not treated adequately may have serious consequences to the pregnant woman and to the fetus. The teratogenicity of the drugs used in treatment of IBD is rarely described but the unknowledgment about this by physicians and patients leads to inadvertent discontinuation of treatment. However, the controlling the activity of the disease is the main determinant of the good prognosis of pregnancy.

\section{Clinical manifestations during the pregnancy}

The manifestations of IBD during the pregnancy are the same of that in non-pregnancy. The majority of pregnancies in patients with IBD, although classified as high risk, courses without several complications ${ }^{(26 \text {, }}$ ${ }^{27}$. Reports of clinical exacerbation, especially in the first trimester, occurs in up to one third of pregnant women with $\mathrm{IBD}^{(24,27)}$. Bortoli et al. ${ }^{(8)}$ found recurrence rates of disease in $17.3 \%$ of women that were in remission, being more frequent in patients with idiopathic ulcerative rectocolitis (IUR) compared to those with Crohn's disease (CD), but without statistical difference $(P=0.38)$. Nineteen percent of births occurred during clinical exacerbations and $8.7 \%$ during remission, all carriers of $\mathrm{IUR}^{(8)}$. Riis et al. ${ }^{(49)}$ analyzing cohort study in 508 women diagnosed with IBD before or after pregnancy, have not observed differences in the pattern of disease or need for surgery for their adequate control, but identified reduction in the number of episodes of clinical exacerbation, after pregnancy. However, the risk of clinical exacerbations is no greater than any other period in life ${ }^{(1)}$.

Furthermore, the adequate control of disease activity seems to be the main prognostic factor in pregnancy ${ }^{(1,4,24,28)}$. Disease activity is associated with increased number of spontaneous abortions, premature deliveries, babies born with low weight and/or small for gestational age and increased demand for surgical deliveries ${ }^{(11,18,28,35)}$. However, the DII does not increase the risk of maternal complications such as hypertension or proteinuria ${ }^{(11)}$.

Regarding IUR, about $70 \%-80 \%$ of patients remain in remission during pregnancy and rates of relapse are similar to non pregnant ${ }^{(28)}$. Up to $7 \%$ present the first episode of colitis during pregnancy or puerperal period ${ }^{(58)}$. Carriers of ileum-anal anastomosis tolerate pregnancy better and exacerbations have more light and transient, resolving completely up in the post-partum period ${ }^{(28)}$. The rates of cesarean sections are higher in carriers of the disease, although IUR by itself represents no formal indication for this route of delivery ${ }^{(28)}$.

The behavior of CD pattern is similar to the IUR during pregnancy. If the design is done in time to clinical remission, this is kept up to $70 \%$ of patients. Relapses occur most often during the first trimester and puerperium. Nor is there consensus on the route of delivery indicated, should be considered obstetric indications $^{(28)}$.

Women with IBD have a risk twice higher than the general population to have premature births

Universidade Federal de São Paulo, Escola Paulista de Medicina, São Paulo, SP, Brazil.

The authors have no interest to disclosure. There is no financial support to this paper.

Correspondence: Dr. Lucianna Motta Correia - Rua Afonso Celso, 1102 - apt. 101 - Vila Clementino - 04119-061 - São Paulo, SP, Brazil. E-mail: Ipmpcorreia@gmail.com 
or children considered of low birth weight and greater likelihood of surgical deliveries, which seems more related to activity of disease than the side effects of medications ${ }^{(18}$, $44,51)$. Otherwise, the pregnancy can be quite normal in this group of patients ${ }^{(4,51)}$. The best obstetric prognostic factor is the control of disease ${ }^{(1,4)}$.

\section{Diagnosis during the pregnancy}

Peculiarities in the diagnosis in this situation should be remembered. The evidence of inflammatory activity are commonly altered in pregnancy without necessarily reflecting activity of disease, but the levels of C-reactive protein (CRP) tends to be elevated in this period and may be useful as markers. Because of hemodilution, the hemoglobin and albumin are little reliable parameters for evaluation of activity and it decreases with the progression of pregnancy. Iron deficiency is common in this situation and should not be used as a marker of blood loss ${ }^{(54)}$. Regarding the endoscopic examinations, the retossigmoidoscopy is relatively safe and may help in the diagnosis of active colitis. In addition, the safety of colonoscopy is still questionable during pregnancy ${ }^{(9,12,52)}$.

Radiologic investigation should be avoided, unless perforation, toxic megacolon or obstruction are suspected ${ }^{(26)}$. Ultrasound and magnetic resonance are safe for use in this situation $^{(26)}$.

Furthermore, pregnancy does not appear to influence the course of the disease or the need for surgical treatment, but appears to be associated with reduced number of relapses over the next years ${ }^{(4,49)}$.

\section{Treatment of IBD during pregnancy and breastfeeding}

\section{Nutritional support}

Acid folic supplementation is recommended for all pregnant woman, especially in use of sulfasalazine or in disease activity ${ }^{(26)}$. The recommended doses are $5 \mathrm{mg} / \mathrm{day}$. In pregnant women in use of steroids, the supplement of vitamin D should be administered ${ }^{(26)}$. Precoce nutritional supplementation is recommended to pregnant women with no weight gain during disease activity ${ }^{(26)}$. Total parenteral nutrition should be initied in very sick patients ${ }^{(26)}$.

\section{Drug therapy}

The drug in this context is perhaps the biggest source of doubt regarding the clinical management of IBD in pregnancy. We describe the medical treatment more frequent used in this condition.

\section{a) Aminossalicilates}

The use of aminossalicilates has been relatively safe, included during breastfeeding ${ }^{(26)}$. The sulfasalazine (SSZ), considered as Class B by the Food and Drugs Administration (FDA), crosses the placental barrier and reaches the fetus in concentrations similar to maternal, not related to increased morbidity or fetal abortions ${ }^{(28,32,34,40)}$. However, some previous reports have described potential teratogenicity for this $\operatorname{drug}^{(19,}$ ${ }^{30,42)}$. There are some studies that describe neonatal jaundice with $\operatorname{SZA}^{(17,58)}$. The replacement of folic acid is recommended because of the antagonistic effects of SSZ, interacting with the cell membrane transporters.

The mesalazine (MZA) in conventional doses is safe during pregnancy ${ }^{(21)}$ and in higher doses (above $3 \mathrm{~g} / \mathrm{d}$ ) at risk of developing interstitial nephritis in newborn ${ }^{(17)}$ but without teratogenicity ${ }^{(17,21,38)}$. It is also considered Class B drug for use during the pregnancy. It is excreted in breast milk, without significant risk to newborn ${ }^{(15)}$.

\section{b) Corticosteroids}

Steroids seem to be safe during pregnancy, with no convincing evidence of teratogenicity ${ }^{(40)}$. They are indicated in moderately to severe cases ${ }^{(1)}$. Findings of low birth weight and newborns small for gestational age during the use of prednisolone during pregnancy have not been confirmed in more recent studies ${ }^{(25,41,48)}$. It is classified as Class $\mathrm{C}$ for use during pregnancy. The prednisolone should be the choice because of the fetal exposure is lower when compared with betamethasone and dexamethasone ${ }^{(7,20)}$.

In a metanalysis, prednisone increases to 3.4 -fold the risk of oral cleft, but without major complications in therapeutic doses $^{(45)}$. However, oral budesonide seems to be safe, in doses 6 to $9 \mathrm{mg} / \mathrm{d}$, without reports of maternal adrenal suppression, glucose intolerance, ocular side effects, hypertension or fetal congenital abnormalities ${ }^{(3)}$. There seems to be no significant placental transfer of topical corticosteroids, but there is a small number of researches ${ }^{(28)}$. Its use seems to be safe in the first trimester and the benefits outweighed the risks of activity disease uncontrolled ${ }^{(26)}$. The administration rote, oral, parenteral or topic, depends to severity of disease activity and tolerability of patient.

\section{c) Immunosuppressive drugs}

There is no evidence so far of adverse effects of azathioprine (AZA) when the adequate doses ${ }^{(50)}$. Despite apparent certainty as to the use is not recommended the initiation of therapy during pregnancy for its potential myelotoxicity, but for those who already are in therapy to maintain the suspension is not necessary. The 6-mercaptopurine (6 MP) increases the risk of miscarriage and premature births in humans and its use is inadvisable during gestation ${ }^{(24)}$. Drugs are considered by the FDA for use class D during pregnancy. The 6-MP excretion in the breast milk occurs within the first 4 hours after intake, with low concentration to the newborn ${ }^{(15)}$. The use during breastfeeding should be recommended ${ }^{(5)}$.

The use of cyclosporine (class $\mathrm{C}$ ) should be considered only in severe cases not responsive to steroids, to avoided emergency colectomy that presents elevated mortality ${ }^{(23)}$. Its use has been related to prematurity and fetal growth retardation, in addition to the potential risk of renal and hepatic toxicity in pregnancy use ${ }^{(24)}$. In doses that aimed for blood levels $200 \mathrm{ng} / \mathrm{mL}$ seems to be safe in inducing remission in patients with several activity of $\operatorname{IUR}^{(47)}$.

Methotrexate (MTX) is an alternative to AZA in patients with steroid refractoriness. Is contraindicated in pregnancy 
for its mutagenic and teratogenic effects, because interferes in acid folic metabolism and purine syntheses ${ }^{(26)}$. It is being associated with cranio-facial malformations, central nervous system abnormalities, including anencephaly, and defects in members ${ }^{(39,46)}$. If a pregnancy occurs during its use, the drug should be suspended immediately and pregnant women should receive high doses of folic acid ${ }^{(22)}$.

Tacrolimus is an immunosuppressant with action similar to cyclosporine. It is contraindicated to breastfeeding ${ }^{(26)}$ and is associated to perinatal hyperkalemia and prematurity ${ }^{(31)}$.

Thalidomide is an option to refractory CD but is an drug class $\mathrm{X}$ for FDA and contraindicated to pregnant women and breastfeeding ${ }^{(26)}$.

\section{d) Antibiotics}

The use of antibiotics may be necessary at times during the treatment of patients with IBD, especially Crohn's disease. The drug metronidazole is teratogenic in animals, but does not appear to be associated with deleterious effects on humans ${ }^{(10)}$. However, there are few data available with respect to their effects at higher doses and for longer periods, as is usually necessary in patients with IBD. Potential toxicity is related with long-term use while breastfeeding ${ }^{(37)}$.

Ciprofloxacin and other quinolones have been used in pregnant women without evidence of congenital or musculoskeletal abnormalities in children and should be avoided its use in the first trimester ${ }^{(26)}$. However, more studies are needed to confirm ${ }^{(6)}$. Its use seems to be safe in breastfeeding ${ }^{(26)}$. Tetracycline and sulfonamides are contraindicated in pregnancy ${ }^{(13)}$. Amoxicilin with or no clavulinic acid is compatible with breastfeeding and does not increase the risks for congenital anomalies ${ }^{(6)}$.

\section{e) Biological therapy}

The biological therapy with infliximab has changed the course of IBD considered refractory. So far, no evidence of adverse effects (maternal toxicity, embryotoxicity, teratogenicity) with its use during pregnancy in isolated models animals ${ }^{(24)}$. Report described complications such as premature birth, tetralogy of Fallot and neonatal death in intracerebral hemorrhage and/or the lung in humans ${ }^{(53)}$.
Infliximab is a chimeric monoclonal antibody against tumor necrosis factor alpha (TNF- $\alpha$ ), considered effective for both induction and for maintenance of clinical remission of the $\mathrm{CD}^{(36)}$. The initial dose, administered intravenously, is $5 \mathrm{mg} / \mathrm{kg}$ at week 0,2 and 6 for induction of response and maintained this dose every 8 weeks for maintenance of remission. It is classified as FDA class B drugs for use during pregnancy. There are few isolated reports of associated malformations ${ }^{(53)}$, but most studies have been favorable to its use in period ${ }^{(43)}$. What is known, however, is that efforts should be made to control the IBD during pregnancy, as activities with greater intensity may put at risk both the mother and the fetus. The outcomes in pregnant women seems not different that in the general population $^{(33)}$.

Serum levels of infliximab can be found in newborns of mothers who used this medication during pregnancy ${ }^{(56)}$. What can explain this fact is the transplacental transfer of maternal antibodies in the first quarter, as it is an antibody of Class $\operatorname{IgG}^{(36)}$. In some reports found, this transfer does not seem to be harmful to the fetus (Table 1) and, similar to other maternal antibodies, infliximab has a half-life prolonged in the newly born ${ }^{(36)}$. There is no evidence of excretion this drug in the mother's milk ${ }^{(54,56)}$.

Adalimumab is classified as class B drugs for use during pregnancy. In a case report with the use of adalimumab found no morbidity related to this medication ${ }^{(55)}$. There is no date on its safety on breastfeeding until the moment ${ }^{(29)}$.

Aussalah at al. ${ }^{(2)}$ report a case of a pregnant woman that was successfully treated with certulizumab but the safety of certulizumab is unknown.

\section{CONCLUSIONS}

Fear of congenital malformations and/or severe side effects or birth defects related to medications is the main responsible for the difficulty in obtaining effective treatment during pregnancy. However, the prognostic factor of major importance in pregnant women suffering from inflammatory bowel disease is adequate control of disease activity in this period. Clarification of the patients and physicians to this fact may reduce complications.

TABLE 1. Case reports

\begin{tabular}{|c|c|c|c|c|c|}
\hline Reference & $\mathrm{n}$ & Disease & Drug & Infusion & Results \\
\hline Roux et al. ${ }^{(51)}$ & 3 & RA & Etanercept, adalimumab & Maintenance & $\begin{array}{l}\text { Prematurity, neonatal jaundice, neonatal urinal infection, } \\
\text { hereditary congenital adrenal hyperplasia }\end{array}$ \\
\hline Vasiliauskas et al. ${ }^{(56)}$ & 1 & Crohn & $\begin{array}{l}\text { Infliximab } \\
(10 \mathrm{mg} / \mathrm{kg})\end{array}$ & Maintenance & Normal birth without comorbidities \\
\hline Mahadevan et al. ${ }^{(37)}$ & 10 & Crohn & Infliximab & $\begin{array}{l}2 \text { induction } \\
8 \text { maintenance }\end{array}$ & 3 premature births and 1 low birth weight \\
\hline Katz et al. ${ }^{(33)}$ & 96 & Crohn, RA & Infliximab & Maintenance & $\begin{array}{l}\text { Spontaneous abortions in } 15 \% \text { and therapeutic abortions in } \\
19 \% \text {. Results did not differ from those of other patients with } \\
\text { Crohn's disease, who did not receive infliximab }\end{array}$ \\
\hline Chakravarty et al. ${ }^{(14)}$ & 2 & RA & Infliximab & Maintenance & Without findings of teratogenicity or maternal morbidities \\
\hline Palmer et al. ${ }^{(44)}$ & 1 & RCUI & Infliximab & Induction & Fetal obit \\
\hline
\end{tabular}


Correia LM, Bonilha DQ, Ramos JD, Ambrogini O, Miszputen SJ. Tratamento da doença inflamatória intestinal durante a gravidez: revisão da literatura. Arq Gastroenterol. 2010;47(2):197-201.

RESUMO - Contexto - A doença inflamatória intestinal acomete mulheres em idade fértil com relativa frequência. A conduta exige maior atenção durante esta condição clínica em virtude dos riscos potenciais de complicações materno-fetais. Resultados e conclusões - Esta é uma revisão sobre as manifestações clínicas das doenças inflamatórias intestinais durante a gravidez e seu tratamento durante este período. Ainda são necessários estudos sobre o tema para melhor abordagem das doenças inflamatórias intestinais em gestantes.

DESCRITORES - Enteropatias inflamatórias. Complicações infecciosas na gravidez. Infliximab.

\section{REFERENCES}

1. Alstead EM, Nelson-Piercy C. Inflammatory bowel disease in pregnancy. Gut. 2003;52:159-61.

2. Aussalah A, Bigard MA, Peyrin-Biroulet L. Certolizumab use in pregnancy. Gut. 2009;58:608.

3. Beaulieu DB, Ananthakrishnan AN, Issa M, Rosenbaum L, Skaros S, Newcome JR, Kuhlmann RS, Otterson MF, Emmons J, Knox J, Binion DG. Budesonide induction and maintenance therapy for Crohn's disease during pregnancy. Inflamm Bowel Dis. 2009;15:25-8.

4. Beniada A, Benoist G, Maurel J, Dreyfus M. Inflammatory bowel disease in pregnancy: report of 76 cases and review of the literature. J Gynecol Obstet Biol Reprod. 2005;34:581-8.

5. Berkovitch M, Pastuszak A, Gazarian M, Lewis M, Koren G. Safety of the new quinolones in pregnancy. Obstet Gynecol. 1994;84:535-8.

6. Berkovitch M, Diav-Citrin O, Greenberg R, Cohen M, Bulkowstein M, Shechtman S, Bortnik O, Arnon J, Ornoy A. First-trimester exposure to amoxycillin/clavulanic acid: a prospective, controlled study. Br J Clin Pharmacol. 2004;58:298-302.

7. Blanford AT, Murph BE. In vitro metabolism of prednisolone, dexamethasone, betamethasone, and cortisol by human placenta. Am J Obstet Gynecol. 1977;127:264-7.

8. Bortoli A, Saibeni S, Tatarella M, Prada A, Beretta L, Rivolta R, Politi P, Ravelli P, Imperiali G, Colombo E, Pera A, Daperno M, Carnovali M, de Franchis R, Vecchi M; Study Group for Inflammatory Bowel Diseases GSMII.. Pregnancy before and after the diagnosis of inflammatory bowel diseases: retrospective case-control study. J Gastroenterol Hepatol. 2007;22:542-9.

9. Burtin P, Frank B. Endoscopy during pregnancy. In: Karlsadt RG, editor Gastrointestinal disorders during pregnancy. Arlington: American College of Gastroenterology; 1994. p.24-9.

10. Burtin P, Taddio A, Ariburnu O, Einarson TR, Koren G. Safety of metronidazole in pregnancy: a meta-analysis. Am J Obstet Gynecol. 1995;172:525-9.

11. Calderwood AH, Kane SV. IBD and pregnancy. Med Gen Med. 2004;6:14.

12. Cappell MS, Colon VJ, Sidhom OA. A study of 10 medical centres of the safety and efficacy of 48 flexible sigmoidoscopies and 8 colonoscopies during pregnancy with follow-up of fetal outcome and with comparison to control groups. Dig Dis Sci. 1996;41:2353-61

13. Caprilli R, Gassull MA, Escher JC, Moser G, Munkholm P, Forbes A, Hommes DW, Lochs H, Angelucci E, Cocco A, Vucelic B, Hildebrand H, Kolacek S, Riis L, Lukas M, de Franchis R, Hamilton M, Jantschek G, Michetti P, O’Morain C, Anwar MM, Freitas JL, Mouzas IA, Baert F, Mitchell R, Hawkey CJ; European Crohn's and Colitis Organisation. European evidence based consensus on the diagnosis and management of Crohn's disease: special situations. Gut. 2006;55(suppl 1):i36-i58.

14. Chakravarty EF, Sanchez-Yamamoto D, Bush TM. The use of disease modifying antirheumatic drugs in woman with rheumatoid arthritis of childbearing age: a survey of practice patterns and pregnancy outcomes. J Rheumatol. 2003;30: 241-6.

15. Christensen LA, Rasmussen SN, Hansen SH. Disposition of 5-aminosalicylic acid and $\mathrm{N}$-acetyl-5-aminosalicylic acid in fetal and maternal body fluids during treatment with different 5-aminosalicylic acid preparations. Acta Obstet Gynecol Scand. 1994;73:399-402.

16. Christensen LA, Dahlerup JF, Nielsen MJ, Fallingborg JF, Schmiegelow K. Azathioprine treatment during lactation. Aliment Pharmacol Ther. 2008;28: 1209-13.

17. Colombel JF, Brabant G, Gubler MC, Locquet A, Comes MC, Dehennault M, Delcroix M. Renal insufficiency in infant: side-effect of prenatal exposure to mesalazine? Lancet. 1994;344:620-1.

18. Cornish J, Tan E, Teare J, Teoh TG, Rai R, Clark SK, Tekkis PP. A meta-analysis on the influence of inflammatory bowel disease on pregnancy. Gut. 2007;56:830-7.
19. Craxi A, Pagliarello F. Possible embryotoxicity of sulphasalazine. Arch Intern Med. 1980;140:1674.

20. Dancis J, Jansen V, Levitz M. Placental transfer of steroids: effect of binding to serum albumin and to placenta." Am J Physiol 1980;238:e208-e13.

21. Diav-Citrin O, Park YH, Veerasuntharam G, Polachek H, Bologa M, Pastuszak A, Koren G. The safety of mesalazine in human pregnancy: a prospective controlled cohort study. Gastroenterology. 1998;114:23-8.

22. Donnenfeld AE, Pastuszak A, Noah JS, Schick B, Rose NC, Koren G. Methotrexate exposure prior to and during pregnancy. Teratology. 1994;49:79-81.

23. Dozois EJ, Wolff BG, Tremaine WJ, Watson WJ, Drelichman ER, Carne PW, Bakken JL.. Maternal and fetal outcome after colectomy for fulminant ulcerative colitis during pregnancy: case series and literature review. Dis Colon Rectum. 2006;49:64-73.

24. Ferrero S, Ragni N. Inflammatory bowel disease: management issues during pregnancy. Arch Gynecol Obstet. 2004;270:79-85.

25. Gur C, Diav-Citrin O, Shechtman S, Arnon J, Ornoy A. Pregnancy outcome after first trimester exposure to corticosteroids: a prospective controlled study. Reprod Toxicol, 2004;18:93-101.

26. Habal FM, Ravindran NC. Management of inflammatory bowel disease in the pregnant patient. World J Gastroenterol. 2008;14:1326-32.

27. Hanan, IM. Inflammatory bowel disease in the pregnant woman. Compr Ther 1993;19:91-5.

28. Heetun ZS, Byrnes C, Neary P, O’Morain C. Reproduction in the patient with inflammatory bowel disease [review article]. Aliment Pharmacol Ther. 2007;26:513-33.

29. Hoentjen F, van Bodegraven AA. Safety of anti-tumor necrosis factor therapy in inflammatory bowel disease. World J Gastroenterol, 2009;15:2067-73.

30. Hoo JJ, Hadro TA, Von Behren P. Possible teratogenicity of sulfasalazine. N Engl J Med. 1988;318:1128-9.

31. Jain A, Venkataramanan R, Fung JJ, Gartner JC, Lever J, Balan V, Warty V, Starz TE. Pregnancy after liver transplantation under tacrolimus. Transplantation. 1997;64:559-65.

32. Järnerot G, Into-Malmberg MB, Esbjörner E. Placental transfer of sulphasalazine and sulphapyridine and some of its metabolites. Scand J Gastroenterol. 1981;16:693-

33. Katz JA, Antoni C, Keenan GF, Smith DE, Jacobs SJ, Lichtenstein GR. Outcome of pregnancy in woman receiving infliximab for the treatment of Crohn's disease and rheumatoid arthritis. Am J Gastroenterol. 2004;99:2385-92.

34. Khosla R, Willoughby CP, Jewell DP. Crohn's disease and pregnancy. Gut. 1984;25:52-6.

35. Kornfeld D, Cnattingius S, Ekbom A. Pregnancy outcomes in women with inflammatory bowel disease - a population-based cohort study. Am J Obstet Gynecol. 1997;177:942-6.

36. Mahadevan U, Kane S, Sandborn WJ, Cohen RD, Hanson K, Terdiman JP, Binion DG. Intentional infliximab use during pregnancy for induction or maintenance of remission in Crohn's disease. Aliment Pharmacol Ther. 2005;21:733-8

37. Mahadevan U. Fertility and pregnancy in the patient with inflammatory bowel disease. Gut. 2006;55:1198-206.

38. Marteau P, Tennenbaum R, Elefant E, Lémann M, Cosnes J. Foetal outcome in women with IBD treated during pregnancy with oral mesalazine microgranules. Alim Pharmacol Ther. 1998;12:1101-8.

39. Milunsky A, Graef JW, Gaynor MF Jr. Methotrexate induced congenital malformations. J Pediatr. 1968;72:790-5.

40. Mogadam M, Dobbins WO 3rd, Korelitz BI, Ahmed SW. Pregnancy in inflammatory bowel disease: effect of sulfasalazine and corticosteroids on fetal outcome. Gastroenterology. 1981;80:72-6.

41. Moskovitz DN, Bodian C, Chapman ML, Marion JF, Rubin PH, Scherl E, Present $\mathrm{DH}$. The effect on the foetus of medications used in pregnant inflammatory bowel disease patients. Am J Gastroenterol. 2004;99:656-61

42. Newman NM, Correy JF. Possible teratogenicity of sulphasalazine. Med J Aust. 1983;1:528-9. 
43. O'Donnell S, O'Morain C. Use of antitumor necrosis factor therapy in inflammatory bowel disease during pregnancy and conception [review article]. Aliment Pharmacol Ther. 2008;27:885-94.

44. Palmer RB, Poullis AP, Pollok RCG Acute severe colitis in pregnancy treated with infliximab. GastroHep Web site. http://www.gastrohep.com/classcases/classcases. asp?id=35. Updated June 8, 2008.

45. Park-Wyllie L, Mazzotta P, Pastuszak A, Moretti ME, Beique L, Hunnisett L, Friesen MH, Jacobson S, Kasapinovic S, Chang D, Diav-Citrin O, Chitayat D, Nulman I, Einarson TR, Koren G. Birth defects after maternal exposure to corticosteroids: prospective cohort study and meta-analysis of epidemiological studies. Teratology. 2000;62:385-92.

46. Powell HR, Ekert H. Methotrexate-induced congenital malformations. Med J Aust. 1971;2:1076-77.

47. Reindl W, Schmid RM, Huber W. Cyclosporin A treatment of steroidrefractory ulcerative colitis during pregnancy: report of two cases. Gut. 2007;56:1019-36.

48. Reinisch JM, Simon NG, Karow WG, Gandelman R. Prenatal exposure to prednisone in humans and animals retards intrauterine growth. Science. 1978;202:436-38

49. Riis L, Vind I, Politi P, Wolters F, Vermeire S, Tsianos E, Freitas J, Mouzas I, Ruiz Ochoa V, O'Morain C, Odes S, Binder V, Moum B, Stockbrügger R, Langholz E, Munkholm P; European Collaborative study group on Inflammatory Bowel Disease. Does pregnancy change the disease course? A study in a European cohort of patients with inflammatory bowel disease. Am J Gastroenterol. 2006;101:1539-45.
50. Rosenkrantz JG, Githens JH, Cox SM, Kellum DL. (1967). Azathioprine (Imuran) in pregnancy. Am J Obstet Gynecol. 1967;97:708-10.

51. Roux CH, Brocq O, Breuil V, Albert C, Euller-Ziegler L. Pregnancy in rheumatology patients exposed to anti-tumor necrosis factor (TNF)-alpha therapy. Rheumatology (Oxford).2007;46:695-8.

52. Siddiqui U, Denise Proctor D. Flexible sigmoidoscopy and colonoscopy during pregnancy. Gastrointest Endosc Clin N Am. 2006;16:59-69.

53. Srinivasan, R. Infliximab treatment and pregnancy outcome in active Crohn's disease. Am J Gastroenterol. 2001;96:2274-75.

54. Stengel JZ, Arnold HL. Is infliximab safe to use while breastfeeding? World J Gastroenterol. 2008;14:3085-87.

55. Subhani JM, Hamiliton MI. The management of inflammatory bowel disease during pregnancy [review article]. Aliment Pharmacol Ther. 1998;12:1039-53.

56. Vasiliauskas EA, Church JA, Silverman N, Barry M, Targan SR, Dubinsky MC. Evidence for transplacental transfer of maternally administered infliximab to the newborn [case report]. Clin Gastroenterol Hepatol. 2006;4:1255-8.

57. Vesga L, Terdiman JP, Mahadevan U. Adalimumab use in pregnancy. Gut 2005;54:890

58. Willoughby CP, Truelove SC. Ulcerative colitis and pregnancy. Gut. 1980;21:469-74.

Received 22/4/2009.

Accepted 3/9/2009. 